\title{
ОБОСНОВАНИЕ НЕОБХОДИМОСТИ ДИВЕРСИФИКАЦИИ ЗАНЯТОСТИ В ЦЕЛЯХ ПОВЫШЕНИЯ ЕЕ УРОВНЯ И ДОХОДНОСТИ ТРУДА"
}

\author{
(C) 2020 Путихин Ю.Е. \\ кандидат экономических наук, директор Санкт-Петербургского филиала \\ Санкт-Петербургский филиал Финансового университета при Правительстве РФ, \\ Россия, Санкт-Петербург \\ E-mail:putihin@bk.ru \\ (c) 2020 Бурцева К.ю. \\ кандидат экономических наук, доцент Департамента учета, анализа и аудита, \\ Финансовый университет при Правительстве Российской Федерации, Россия, Москва \\ E-mail: aksentiya@mail.ru \\ (c) 2020 Путихин К.ю. \\ аспирант Департамента учета, анализа и аудита, \\ Финансовый университет при Правительстве Российской Федерации, Россия, Москва \\ E-mail: putihin@bk.ru
}

На фоне дискуссий о необходимости освобождения отечественной экономики от нефтяной зависимости, с середины 2000-х годов, концепция диверсификации приобрела очень широкую интерпретацию и стала своего рода синонимом экономической модернизации и улучшения производства в регионах. В официальных документах и научных публикациях диверсификация считается основной стратегией долгосрочного развития всего экономического сектора страны. Вопросам развития хозяйственной деятельности и повышению уровня занятости сельского населения посвящено немало исследований, в статье рассмотрены некоторые из них с целью обоснования необходимости диверсификации занятости, повышения ее уровня и доходности труда.

Ключевые слова: занятость, диверсификация занятости, диверсификация сельской занятости, диверсификация экономики, механизмы поддержки диверсификации.

Организация Объединённых Наций определяет экономическую диверсификацию как диверсификацию рынков для экспорта или диверсификацию источников дохода от внутриэкономической деятельности. Данное понятие отражает процесс перехода экономики от сильно централизованной к менее централизованной. Диверсификация экономики некоторых стран и регионов традиционно считались инструментом уменьшения зависимости от одного источника роста, как правило, сырья [1,2]. Во многих экономических исследованиях [3,4,5] выражается точка зрения, что преимущество диверсифицированных экономик заключается в их меньшей чувствительности к колебаниям динамики некоторых секторов, в том числе к ценовым шокам.

Диверсифицированная экономика предоставляет более широкие возможности для эф- фективной занятости, смягчения потрясений сразу в нескольких секторах, а также для создания более гибкого рынка труда в регионах (из-за межотраслевой мобильности труда). Значительное региональное сопротивление внешним факторам является аргументом в пользу диверсификации производственной структуры, в том числе и внешнего спроса, потому что формирование внутреннего спроса в многоотраслевой структуре обеспечивается за счет межотраслевых связей. Традиционно, у стран с низкими показателями диверсификации также менее развитая экономика. Наблюдается сильная зависимость от агропромышленности или добычи природных ресурсов и экспорта продуктов переработки.

«Концепция устойчивого развития сельских территорий РФ на период до 2020 г.» ставит перед государством определенные задачи по обеспечению продовольственной безопасности,

\footnotetext{
* Статья подготовлена по результатам исследований, выполненных за счет средств по государственному заданию Финуниверситета
} 
повышению конкурентоспособности экономики России и улучшению уровня жизни граждан. Именно при данных целевых направлениях развития диверсификация сельской экономики в целом, рассматривается одним из основных способов развития сельских территорий. Вопросам развития хозяйственной деятельности и повышению уровня занятости сельского населения посвящено немало исследований, рассмотрим некоторые из них с целью обоснования необходимости диверсификации занятости, повышения ее уровня и доходности труда.

В своем исследовании «Диверсификация занятости как фактор повышения доходности труда сельского населения» [6] В.А.Богдановский утверждает, что диверсификацию можно достигнуть путем усиления разнообразия хозяйственной деятельности и альтернативных видов хозяйствования. Автор предложил рекомендации по предотвращению тормозящих сил развития сельскохозяйственной и несельскохозяйственной деятельности на селе. Во-первых, усилить стимулирующую поддержку государства в части кредитно-финансового обеспечения и льготного налогообложения. Во-вторых, выразил необходимость в применении мер по подготовке кадров, развитию необходимой инфраструктуры и консультационных услуг.

Х.У.Абасова в своем исследовании «Диверсификация занятости на основе многофункционального развития сельских территорий» [7] отмечает, что диверсификация необходима и ее достижение возможно путем стимулирования несельскохозяйственной деятельности. Это позволит ускорить развитие сельских территорий и, тем самым, сократит риски безработицы и бедности. Автор считает, что необходимо устранить монополию аграрного производства, развивая при этом другие сферы деятельности: торговля, энергетика. Для решения проблем, имеющих место в сельскохозяйственной деятельности, автор приводит те же способы решения, что и В.А. Богдановский, а также указывает на то, что в перспективе развития АПК потребность кадрах будет только расти. Этот процесс будет сопровождаться диверсификацией занятости и созданием дополнительно рабочих мест.

А.И. Костяев в исследовании «Диверсификация сельской занятости в условиях аграрной модернизации» [8] решение выявленных проблем видит в диверсификации сельской экономики на основе индустриальных парков (ИП), которые представляют собой организованные территории или площадки, обеспеченные необходимой инфраструктурой и средствами. Также предоставление грантов для поддержки фермеров и развитие семейных ферм может стать одним из способов решения проблемы занятости населения.

В исследовании «Разработка направлений диверсификации сельской экономики в регионах России с учетом потенциала малых городов» [9] коллектив авторов рассмотрел основные способы диверсификации сельской экономики, определили стратегии и направления развития, связанные и не связанным с сельским хозяйством. Авторы в своем исследовании сделали следующие выводы: диверсификация сельской экономики, которая может быть достигнута разными направлениями - один из главных способов повышения устойчивости развития сельских территорий в ближайшей перспективе. Это может привести не только к усилению межотраслевой интеграции, но и созданию дополнительных рабочих мест в разных областях деятельности, повышению занятости и доходности труда.

Рассмотрим диверсификацию занятости на примере стран с различным уровнем развитости экономик (Афганистана, Саудовской Аравии, Нигерии и Индии) для обоснования ее необходимости в целях повышения уровня и доходности труда.

Отсутствие работы в Афганистане является постоянно отмечаемой проблемой в большинстве исследований. Низкое количество рабочих мест как в сельскохозяйственном секторе, так и в сфере услуг, вынуждает молодое население страны искать работу в зарубежных странах, в основном это страны постсоветского пространства. В условьях создавшейся ситуации вопрос о создании рабочих мест в Афганистане жизненно важен как для улучшения уровня жизни и жизнеобеспечения, так и для снижения региональной напряженности.

Во многих развивающихся странах политика распределения доходов и трудоустройства является теневой, то есть не регулируется неофициальными государственными институтами, а представляет интересы отдельно взятых лиц. Данное неравенство порождает ряд важных проблем: отсутствие жилья и коммунальных услуг, слабая развитость сектора здравоохранения; высокий уровень инвалидности; отсутствие доступа к мужскому труду в некоторых хозяйствах; низкий уровень человеческого капитала и т.д. 
Государство не имеет возможности позитивно и радикально изменить создавшуюся ситуацию из-за низкого институционального потенциала, преобладания неофициальных «законов», сильного влияния традиций и религии (строгие гендерные нормы и роли не позволяют качественно распределять обязанности), а также высокой самостоятельности региональных и местных властей. В исследовании [10] выявлено позитивное и негативное влияние трудовой диверсификации на экономическую ситуацию в Афганистане в целом, представлены результаты исследования изучения диверсификации труда и ее результатов в Кабуле. Приведены некоторые рекомендации о том, как приступить к созданию политической среды, благоприятствующей городской бедноте, отражающей текущие процессы, такие как утверждение нового трудового кодекса, плановое развитие национальной занятости, политика и разработка Национальной стратегии развития Афганистана, а также Документов о стратегии сокращения масштабов нищеты страны. Новый трудовой кодекс должен продвигать права трудящихся и достойную работу посредством положений о ряде важных льгот, таких как отпуск по беременности и родам, уведомление об увольнении, а также стандарты здоровья и безопасности. Связанные с занятостью показатели в рамках процесса сокращения масштабов нищеты в стране разделены на два социальных сектора: защиты и развития села. Последний имеет дело главным образом с краткосрочной экстренной занятостью и кредитами на развитие предпринимательства, тогда как первый не выходит за рамки политики увеличения занятости для женщин, молодежи, инвалидов и демобилизованных солдат. Проблемы занятости в городах рассматриваются лишь в общем. Таким образом, Министерство труда и социальных дел, в объединении с другими соответствующими министерствами и внешними учреждениями, должны более решительно выступать за гораздо более централизованный подход для создания рабочих мест. Это должно простимулировать зарождающиеся усилия по разработке национальной политики занятости, которая должна учитывать вопросы занятости городских и сельских жителей, включая подгруппы, которые, как правило, имеют неравный доступ к рынку труда - женщины, дети и инвалиды. Оба подхода придерживаются чрезмерно технической реализации, не основанной на местном анализе, то есть того, как люди должны зарабатывать на жизнь, уровень доступа к работе в институциональной среде, который часто является очень низким в бедной среде.

Таким образом, переосмысление нынешней модели развития Афганистана необходимо, чтобы избежать критической перспективы социального развития. Изменения должны включать в себя: институциональный анализ в рамках социально-экономической политики, переосмысление роли власти во влиянии на национальное благосостояния, а также решение вопросов неравенства и социальные изменения в политическом центре. Именно благодаря внедрению подхода диверсификации во всех социальных институтах страны поможет быстро разработать и внедрить более совершенный механизм функционирования экономики.

В исследовании «Влияние экономической диверсификации на трудоустройство выпускников» [11] рассматривается пример Саудовской Аравии. За последние 10 лет правительство Саудовской Аравии предпринимало попытки диверсификации источников дохода, и старалось увеличить долю других секторов, которые являются бюджетонаполняющими. Связано это с тем, что страна имеет сильную зависимость от нефтепродуктов и их экспорта. В последние десятилетия спрос на нефть и газ увеличился, и экономика Саудовской Аравии стала сильно зависеть от доходов данного сектора.

Экономическая диверсификация считается серьезной задачей для многих развивающихся стран. В особенности стран, где доминируют сектора экономики связанные с природными ресурсами и сельским хозяйством. Данные страны подвержены несбалансированному росту и экономическим шокам, таким как быстрое изменение цен на природные ресурсы (нефть, газ, минералы) или нестабильные погодные условия, которые отрицательно влияют на урожайность и работу сельского хозяйства [11]. Страны с более диверсифицированными экономиками лучше переносят подобные потрясения. Авторы исследовали связь безработицы и диверсификации экономики, ставя цель доказать потенциальные плюсы диверсифицированной экономики для выпускников ВУЗов Саудовской Аравии. Они предположили, что диверсификация экономики положительно сказывается на уровне занятости населения страны в целом. Авторы задались вопросом: влияет ли диверсификация экономики 
на занятость выпускников Саудовской Аравии? В практической части исследования авторы формулировали 3 гипотезы:

1. ЭД (экономическая диверсификация) имеет значительное и положительное влияние на уровень безработицы выпускников-бакалавров.

2. ЭД имеет значительное и положительное влияние на уровень безработицы выпускниковмагистров.

3. ЭД имеет значительное и положительное влияние на уровень безработицы выпускниковкандидатов наук (или докторов наук).

Чтобы проверить данные гипотезы, авторы предположили влияние ЭД и ВВП на нетрудоустроенных выпускников по уровню образования и создали модель. Результаты полученных расчетов, согласно разработанной модети, позволили сделать заключение о взаимодействии между уровнем безработицы среди выпускников бакалавров, ЭД и ВВП. Эмпирические результаты показали отрицательную и значительную связь. Нижнее значение (менее 0,05 ) р-значения указало на то, что ЭД статистически влияет на уровень безработицы среди выпускников бакалавров. Реальный ВВП оказывает существенное влияние на уровень безработицы среди выпускников бакалавров на уровне 5 процентов. Результаты исследования также показали взаимодействие между уровнем безработицы среди выпускников магистров, ЭД и ВВП. Существует позитивная связь между ЭД и уровнем безработицы среди выпускников магистров. Реальный ВВП имеет негативное влияние на уровень безработицы среди выпускников магистров. И существует позитивная связь между уровнем безработных выпускников кандидатов наук и ЭД и ВВП.

В проведенном исследовании [11] авторы ожидали, что экономическая диверсификация оказывает положительное влияние на занятость выпускников. Результаты показали, что переменная ЭД статистически значима для выпускников. Однако, что касается выпускников со степенью бакалавра, зависимость отрицательна. Это подтверждает, что экономическая диверсификация в Саудовской Аравии не достигла значительного уровня. Учитывая негативное влияние экономической диверсификации на трудоустройство выпускников бакалавриата, Саудовская Аравия должна диверсифицировать свою экономику чтобы снизить уровень безработицы среди бакалавров.
Далее, рассмотрим похожий на Саудовскую Аравию пример Нигерии. В статье «Экономическая диверсификация и экономический рост: пример Нигерии» [12] рассматривается вопрос: насколько Нигерии может быть полезна диверсификация экономики? В последние года экономика Нигерии росла, однако уровень бедности не снижался и не создавалось большее количество рабочих мест. Объяснение такой парадоксальной ситуации состоит в том, что около $80 \%$ выручки с экспорта нефти сконцентрировано в руках менее $1 \%$ населения страны. Эмигранты и члены правящих элит, которые контролируют добычу и продажу нефтепродуктов, преобладают среди данного пласта населения. Данный сектор экономики часто не связан с другими секторовами, что не дает мультиплицирующего эффекта.

Согласно статистике Министерства Финансов Нигерии, нефть занимает, по разным оценкам, от 80 до 87 процентов выручки и 95 процентов выручки от экспорта. Данная ситуация хороша для страны в моменты высоких цен на нефть, но также это и рисковая ситуация в виду периодических снижений цен. Существует позитивный аспект подобной зависимости. Инвестируя выручку от данного сектора в смежные сектора экономики можно диверсифицировать источники дохода. Исследуя данные за 19802011 год, авторы приходят к выводу, что диверсификация экономики является способом для прихода к наиболее эффективной модели получения выгоды от торговли. Исследование показывает [12], что «забытый» сектор экономики (не относящийся к нефтепродуктам) может потенциально принести порядка $44 \%$ прироста к национальной торговле. Это также приведет к пропорциональному улучшению экономики и приведет к увеличению количества рабочих мест, что далее приведет к снижению уровня безработицы. Также, исследователи утверждают, что чрезмерная опора не нефтедобывающую индустрию является ошибочной.

В исследовании «Роль диверсификации занятости в снижении подверженности бедности среди мелких сельских хозяйств в Индии» [13] исследуется влияние диверсификации занятости населения на бедные хозяйства Индии. Авторы сделали вывод, что бедность населения напрямую связана с количеством земли, которой они владеют. Класс, ниболее подверженный бедности - хозяйства без земли либо с незна- 
чительным ее количеством. Исследование показало, что диверсификация занятости является эффективной для населения не занятого с сфере сельского хояйства.

В заключении отметим, что сельскохозяйственным странам очень сложно обеспечить достойный уровень заработной платы и диверсификации. Как правило, рабочая сила очень дешевая, масштаб работ мелкий и не особо распространено развитие и использование современных технологий. Часть сельскохозяйственной продукции, полученной в результате труда идёт на «перекрытие» нужд населения, другая большая идёт на экспорт. Это и является основной статьей доходов и главным образом формирует ВВП.

Что касается стран нефтедобывающих, Саудовской Аравии, России, Нигерии, то, как прави- ло, страны крайне зависимы от доходов с продажи нефти. Во многих случаях наблюдается (как в Нигерии) экспорт продуктов добычи, без обработки на месте. Следовательно, не создаются новые рабочие места (фабрики и т.д), а нефть просто продается на экспорт. Наблюдается отсутствие квалифицированной рабочей силы, нет развития индустрии, нет новых рабочих мест и диверсификации, соответственно.

Диверсификация труда и экономики в целом позволит меньше концентрироваться на одном ресурсе, обеспечить ее устойчивый экономический рост, а чтобы обеспечить все соответствующие условия для этого и внести вклад в экономическую стабильность неодходима диверсификация местного производства, создание новых рабочих мест и повышение общей производительности.

\section{Библиографический список}

1. Севастьянова А.Е., Шмат В.В. Ситуационный анализ диверсификации экономики нефти и нефтепродуктов газодобывающий регион //, рег .: экон. Социол.-2006.- № 2.- С. 49-66.

2. Диверсификация экономики в GCC: прошлое, настоящее и будущее URL: https://www.imf.org/external/pubs/ $\mathrm{ft} / \mathrm{sdn} / 2014 / \mathrm{sdn} 1412 . p d f$. Дата обращения: 20.04.2020 г.

3. Дуженко Т. И. Диверсификация региональной экономики на основе развития социальной инфраструктуры. Автореф. Sci. (Эконом.) Диссертация, Новосибирск, 2015. URL: http://econom.nsc.ru/ieie/ Новости / zashiti / персоналии / 2015 / dugenko / dissert.pdf. Дата обращения: 20.04.2020 г.

4. Иогман Л. Г. Стратегия диверсификации региональной экономики // экон. Соц. Перемены: Факты, Тенденции, Прогноз.-2008.-№ . 1 (1).- С. 78-91.

5. Сальников В.Диверсификация и расширение экспорта промышленные компании как фактор экономического роста в долгосрочный. URL: http://www.forecast.ru/_ARCHIVE/ Презентации / EcoSchool042008 / vs042008.pps. Дата обращения: 20.04.2020 г.

6. Богдановский В. А. Диверсификация занятости как фактор повышения доходности труда сельского населения // Аграрный вестник Урала. - 2009. - № 11.-С. 13-15.

7. Абасова Х. У. Диверсификация занятости на основе многофункционального развития сельских территорий // Вопросы структуризации экономики. - 2012. - № 1.- С. 60-61.

8. Костяев А.И. «Диверсификация сельской занятости в условиях аграрной модернизации» URL: https:// cyberleninka.ru/article/n/diversifikatsiya-selskoy-zanyatosti-v-usloviyah-agrarnoy-modernizatsii. Дата обращения: 30.04.2020 г.

9. Шерешева М.Ю., Оборин М.С., Шимук О.В Разработка направлений диверсификации сельской экономики в регионах России с учетом потенциала малых городов // Вестник Пермского университета URL: https:// rucont.ru/file.ashx?guid=7e0df932-769f-4558-9283-b480c7b60f98 Дата обращения: 30.04.2020г

10. Diversification and security? Labour mobilization among urban poor households in Kabul, Afghanistan. URL: https://www.researchgate.net/publication/248524273_Diversification_and_security_Labour_mobilization_among_ urban_poor_households_in_Kabul_Afghanistan Дата обращения: 20.04.2020 г.

11. Impact of economic diversification on graduates employment URL: https://www.researchgate.net/profile/ Tahar_Jouili/publication/331446753_Impact_of_economic_diversification_on_graduates_employment/ links/5c7f8bde92851c6950592129/Impact-of-economic-diversification-on-graduates-employment. pdf?origin=publication_detail Дата обращения: 20.04.2020 г.

12. Economic diversification and economic growth: Evidence from Nigeria URL: https://pdfs.semanticscholar.org/102 7/7b107ae2dc229f9023e1084d73f4ff209bc8.pdf Дата обращения: 20.04.2020 г.

13. The Role of Employment Diversification in Reducing Vulnerability to Poverty among Marginal and Small-holder Agricultural Households in India URL: https://journals.sagepub.com/doi/full/10.1177/0973801017740661 Дата обращения: 20.04.2020 г. 